\title{
Firm Structural Characteristics and Financial Reporting Quality of Listed Deposit Money Banks in Nigeria
}

\author{
Olumide A. Olowokure ${ }^{1}$, Muhammad Tanko ${ }^{2}$ \& Terzungwe Nyor ${ }^{3}$ \\ ${ }^{1}$ First City Monument Bank Limited, British America Junction, Jos, Nigeria \\ ${ }^{2}$ Department of Accounting, Kaduna State University, Kaduna, Nigeria \\ ${ }^{3}$ Department of Accounting, Nigeria Defence Academy, Kaduna, Nigeria \\ Correspondence: Olumide A. Olowokure, First City Monument Bank Limited, British America Junction, Jos, \\ Nigeria. Tel: 080-9765-6026, 080-2540-0263. E-mail: oakgate700@yahoo.com; olumide.olowokure@fcmb.com
}

Received: November 15, 2015

doi: 10.5539/ibr.v9n1p106
Accepted: December 1, 2015 Online Published: December 25, 2015

URL: http://dx.doi.org/10.5539/ibr.v9n1p106

\begin{abstract}
The quality of financial report is very crucial as published financial reports remains, for the most part, the only means by which outside shareholders and investors keep themselves informed about the performance of the firm. In the present economic scenario, this concern for financial reporting quality becomes more acute as emerging market economies and more importantly mono economies like Nigeria face greater uncertainties as they combat the challenges of unprecedented fall in oil prices. In addition to this, the suspension of the CEO, Chairman and two other directors of Stambic IBTC bank by the Financial Reporting Council of Nigeria for filling a misleading financial statement for 2013 and 2014 has also shown that the issue of financial reporting quality cannot be overemphasized. Using secondary data from the published reports of thirteen listed deposit money banks in Nigeria for over a period of ten years between 2005 and 2014, this paper seeks to find the determinants of financial reporting quality and reports the findings of the impact of structural characteristics like age, size and level of leverage on financial reporting quality. Using prio studies as a guide, we developed a model for loan loss provisions and generated the residuals, using these residuals know as abnormal loan loss provisions as the dependent variable for the multiple regression analysis, the study did not find any evidence of significant relationship between firm age, size, leverage and financial reporting quality.
\end{abstract}

Keywords: structural characteristics, loan loss provisions, abnormal loan loss provisions, financial reporting quality, leverage

\section{Introduction}

Financial reporting can be described as the process of communicating the financial information of an enterprise to the external world. It is the use of published financial statements and related tools in communicating financial information of a business enterprise to third parties (external users) including shareholders, creditors, customers, governmental authorities and the public (Maharshi, 2004). Financial reporting is a communication system that involves the management of the firm as the preparer, the investors and creditors as primary users, and other secondary users such as the government authorities and the general public. However, it is not always true that management normally present the true picture of the financial position of the enterprise. The recent suspension in 2015 of the CEO, Chairman and two other directors of Stambic IBTC bank by the Financial Reporting Council of Nigeria for filling a misleading financial statement for 2013 and 2014 has validated this and also shown clearly that regulators are now taking the issue of financial reporting quality seriously.

\subsection{Motivation for the Study}

The motivation for this study is in line with the concerns raised by the general public about the quality of the financial statement of firms in Nigeria, especially in the banking industry where several reforms of the Central Bank of Nigeria (CBN) have shown that many deposit money banks (DMB) have been "cooking" their books. Some of the banks that failed in the 2009 CBN reforms had shown strong positive fundamentals in previous financial years. The general argument has been that if the financial reports are anything to go by, those banks should not have been declared illiquid with low capital adequacy ratio by the CBN. The 2009 CBN reforms in Nigeria revealed that nine listed deposit money banks were illiquid with low capital adequacy ratio in variance to 
the disclosures in their previous financial reports.

DMBs in Nigeria like any other firm have different characteristics that will affect the quality of their financial reports (Farrell, Yu, \& Zhang, 2013). For instance, the asset size of a bank has been argued to be a factor likely to have a relationship with the quality of their financial report. A bank with a large asset base may be under immense pressure to engage in earnings management in order to portray a good financial performance.

Presently, there is paucity of studies in this area in Nigeria that used strictly data from the deposit money banks. The study carried out by (Dabor \& Ibadin, 2013) is one of the few. However, the study considered only the corporate governance attributes of the banks leaving out the structural attributes. Besides, the study covered only 5 years period of 2006 to 2010. Other studies in Nigeria in this area focused on listed manufacturing firms. (See, Shehu, 2013; and Shehu \& Ahmad, 2013).

The gaps that the study has identified and which it hopes to fill include; period gap between 2010 and 2014 (Dabor \& Ibadin, 2013) and variable segment gap of structural characteristics.

This study will therefore fill these gaps by looking at the structural characteristics of firms and their effect on financial reporting quality (Wallace, Naser, \& Mora, 1994; Chen \& Jaggi, 2007) and considering them for a period of ten years as against five years in the case of (Dabor \& Ibadin, 2013).

\subsection{Objectives of the Study}

The main objective of the study is to assess the impact of structural characteristics on the quality of financial reporting in listed deposit money banks in Nigeria. To determine the effect of the size of listed DMBs in Nigeria on the quality of their financial reports, to examine the impact of debt financing on financial reporting quality of listed DMBs in Nigeria and to evaluate the relationship between financial reporting quality and the age of listed deposit money banks in Nigeria are the specific objectives that will assist to achieve the main objective of the study. Further, the study hypothesised that there is no significant relationship between firm age, firm size, leverage and financial reporting quality of listed DMBs in Nigeria.

The study is divided into five sections, the first being the introduction, the second section contains the review of literatures; the third section shows the methodology. Further, data was analysed and the findings discussed in section 4 while the last section contains the conclusion of the study.

\section{Literature Review}

A key element of firm attributes is structural characteristics, others are monitoring characteristics and performance characteristics (Wallace, Naser, \& Mora, 1994; Chen \& Jaggi, 2007). The structural characteristics are those attributes that have to do with a firm's structure which is likely to be unique to the firm. Characteristics such as the capital structure which was referred to as leverage by (Shehu \& Ahmad, 2013). The capital structure is of particular interest to this study. It is unlikely that the rate of leverage of all the banks will be the same and even for the same deposit money bank, the level might differ from year to year. The capital structure is a determinant of the quality of financial reports of firms (Shehu, 2013).

Another important structural characteristic is the size of the firm. This will also have implications for the financial reporting quality (Huang, Rose-Green, \& Lee, 2012). Larger firms are able to afford a well-structured internal control system, or to engage the services of one of the top auditing firms for the audit of its financial statement which is expected to improve the quality of their financial report. On the other hand, a large firm can also be motivated to engage in earnings management in order to maintain a certain level of profile (Waweru \& Riro, 2013) this will in turn affect the quality of its financial report.

Finally, the age of the firm is also likely to have repercussions for its financial reporting quality (Huang, Rose-Green, \& Lee, 2012). Some firms over the years have reputation for quality and sound corporate governance and will likely not be involved in activities that will undermine the quality of their financial report.

\subsection{Concept of Financial Reporting Quality}

Financial reporting quality is defined as the faithfulness of the information conveyed by the financial reporting process (Martinez-Ferrero, 2014). The word faithfulness is characterised by relevance, reliability, transparency and clarity (Jonas \& Blanchet, 2000). Relevant information means that the financial statement should contain enough information that the different users of the financial statement will find useful which will assist them in their decision making process and that the information is provided in a timely fashion when they are still "news". Reliability is what assures the users that the information is reasonably free from error or bias and that it truly represents what it is intended to represents. Information in a financial report will be reliable to the extent that users can depend on it to judge the economic conditions or events that it purports to represent (Shehu, 2013). 
Transparency means that the figures are true reflections of the economic activities of the enterprise during the period. Clarity is focused on how the figures are presented. The format and language of presentation is also very important. Financial reporting should therefore provide information to help investors, creditors, and other users to project the amounts and timing of future cash flows to the enterprise (Waweru \& Riro, 2013).

The objective of general purpose financial reporting is to provide financial information about the reporting entity that is useful to existing and potential investors, lenders and other creditors in making decision about providing resources to the entity (FASB, 2010). These users of finanacial information want to make decisions about buying or selling both equity and debt instruments, they want to know how much interest or dividend to expect, they also want to know when to expect the payment of these interest and dividends. Other users that may also find general purpose financial reporting usful are regulators, customers, government agencies and general public others are existing and potential investors, lenders and other creditors (FASB, 2010). The quality of financial reports will be determined by its fitness for purpose which is refered to as usefulness in decision making by the framework. The financial information that will be useful for decision making must be relevant and should faithfully represent what it purports to represent.

\subsection{Empirical Reviews of Structural Characteristics and Financial Reporting Quality}

Leverage refers to the percentage of debt financing in the capital structure of a firm. It is often called gearing ratio (Okwoli, 2009). It is measured by long term debt-to-fixed asset ratio. Waweru and Riro (2013) asserts that highly leverage firms are more likely to engage in earnings management than firms that are not highly leveraged. Shehu 2013 and Shehu and Ahmad 2013 also posit that there is a significant relationship between the degree of leverage and the level of earnings management. The debt covenant hypothesis tries to explain the behaviour of management that decides to use particular accounting policy to achieve certain objectives in order to make lenders to have particular impression about the the firm. In most cases, the impression they pass across to lenders is that the company is doing well and that the investments of the lenders in the company are secured. Hence, they are likely to use accounting policies that will shift furture earnings to current period.

Extant literatures have suggested that there is a significant relationship between firm's leverage and financial reporting quality. The debt covenant hypothesis of Positive Accounting Theory also buttresses this fact. Waweru and Riro (2013) while studying earninings management and firm characteristics using 37 listed firms in Kenya for five year period 2006 to 2010 and employing accounting accural approach to measure earnings management finds that the financial reporting quality of firms that are not highly geared were not compromised. They therefore concluded that investors can rely more on the financial reports of firms with lower debt to equity ratio. Shehu (2013) using the modified Dechow and Dichev's (2002) model on 32 listed manufacturing firms in Nigeria while employing multiple regression technique finds a significant relationship between the degree of leverage and the level of finanacial reporting quality.

Shehu and Ahmad (2013) also studied firm characteristics and financial reporting quality in Nigeria using 24 listed manafacturing firms and adopting correlational research design. Their regression result shows that leverage has significant effect at 5\% level on earnings quality. Valipour and Moradbeygi (2011) also studied the relationship between corporate debt financing and earnings quality collecting data from 81 firms listed on Tehran Stock Exchage (TSE) during the period 2005-2009 and using multiple regression analysis, they reported a significant negative relationship between debt and earning quality. However, the work of (Wallace, R S; Naser, k; Mora, A, 1994; Owusu-Ansah, 1998; Nedal, Bana, \& David, 2010) did not find any significant positive relationship between leverage and financial reporting quality.

The size of the firm is an attribute that affects financial reporting quality (Dechow' \& Ge, 2006). The firm size in most cases is measured by the asset size of the firm (Saheed, 2013). A large firm is expected to have a well structured accounting and internal control department and should be able to afford the services of professionals who are expected to enhance the financial reporting process (Chalaki, Didar, \& Riahnezhad, 2012). They are also likely to have a well built information system that enables them track all financial and non financial information for operational, tactical and strategic purposes (Saheed, 2013). This is because a well structured accounting and internal control department will ensure the integrity of financial report. Internal control procedures are meant to detect and/or prevent both the ability to manipulate earnings as well as mistakes or errors (Dechow' \& Ge, 2006). In addition, they should be able to engage the services of one of the big auditing firms to audit their financial statement which is expected to enhance the quality of financial reporting (Thoopsamut \& Jaikengkit, 2009) reason being that the big audit firms are expected to be very professional in their audit engagements and be concerned about their reputations.

Waweru and Riro (2013) investigated the influence of corporate governance and firm specific characteristics on 
earnings management. The study found that company size is not significantly related to financial reporting quality, this is consistent with the result obtained by (Missonier-Piera, 2004) while investigating the economic choices of accounting method in Swiss and the result obtained by Thoopsamut and Jaikengkit (2009) also laid credence to the assertion that company size is not a significant variable in the determinant of financial reporting quality.

The line of argument above is however contrary to the findings of Thomas (1996) as cited by Waweru and Riro (2013) who assert that company size is a major factor shaping Managers choices of accounting in Japan. Moreover. Shehu and Ahmad (2013) documented that firm size has significant effect on earnings quality. The study argued that large manufacturing firms in Nigeria tends to report more reliable and qualitative information in their financial report than small ones. The reason for this according to the study may be as a result of stong internal control system, governance mechanisms, and ability to access high quality service from large audit firms. The combination of these factors should discourage earnings management which is expected to improve the quality of financial reporting. Moreover, Huang, Rose-Green, and Lee (2012) while studying CEO age and financial reporting quality, using the meeting and beating of analyst earnings forecasts and financial restatements as a proxy for financial reporting quality, a sample of 3,413 firms for a period 2005 to 2008 and employing regression analysis in analysing the variables found that firm size is significant and negatively related to financial reporting quality.

Firm size will also affect the corporate governance characteristics as well as the level of earnings management (Becker, DeFoond, Jiambalvo, \& Subramanyam, 1998). Besides, Shehu and Ahmad (2013) posit that large firms have very strong reasons to manipulate their earnings in order to keep consistent earnings growth trend and meet and beat earnings expectations. Although, Missonier-Piera (2004) and Thoopsamut and Jaikengkit (2009) contrary to Shehu and Ahmed's findings posit that company size is not significantly related to financial reporting quality. Their work was not conducted in an emerging economy. It therefore could be that the reasokn for this divergent result is the level of development of the economies in which the studies were conducted. If firm size is likely to affect the corporate governance characteristics as posited by (Becker, DeFoond, Jiambalvo, \& Subramanyam, 1998) it is likely it will also affect the level of finanacial reporting quality

The age of the firm is a major determinant of the strength of a firm's internal control, while a srong internal control is associated with financial reporting quality (Huang, Rose-Green, \& Lee, 2012). It is believed that the internal control system of a firm becomes better structured as years passes by and a well structured internal control should naturally guaranty the integrity of the financial report (Huang, Rose-Green, \& Lee, 2012). Moreover, with the passage of time, firms are more likely to improve their governance and are more likely to be exposed to political risk. This is because government may not pay attention to new firms while firms that have been around for some time are always on the radar of government agencies. These factors are likely to affect their reporting practices (Chalaki, Didar, \& Riahnezhad, 2012).

Chalaki, Didar, and Riahnezhad (2012) investigated the effect of corporate governance attributes on financial reporting quality in 136 firms listed on Tehran Stock Exchange (TSE) during the period of 2003 to 2011 using a descriptive-correlation design, the study used McNichols (2002) for financial reporting quality measurement while considering institutional ownership, ownership concentration, board independence and board size as corporate governance attributes and audit size, firm size and firm age as controlled variables, the result of the study showed that there is no significant relationship between firm age and finanacial reporting quality. Huang, Rose-Green and Lee (2012) also documented an insignificant relationship between firm age and financial reporting quality using the year of incorporation of such firms to measure the firm age. There is a paucity of research in this area and we are yet to come across any work with a divergent result. This study will like to validate or refute these previous findings using data from deposit money banks.

\section{Research Methodology}

Correlational research design with a positivism paradigm in line with (Huang, Rose-Green, \& Lee, 2012; Shehu 2013; Shehu \& Ahmad, 2013; Waweru \& Riro, 2013) was employed. A correlational research design is very appropriate for this study because it is used to describe the statistical association between two or more variables. The use of this design will allow for the testing of expected relationships between and among variables and the making of predictions regarding these relationships (Shehu, 2013). The population for this study is the listed deposit money banks in Nigeria as at $31^{\text {st }}$ December 2014 as displayed on the website of the CBN. Out of these fifteen listed DMBs, Sterling bank and Unity bank were filtered out as data for 2005 and 2006 were not available for both banks. The remaining thirteen banks were therefore used for this study. The justification for using the entire thirteen listed deposit money banks with complete data and not just a sample is because the entire 
population is not more than thirteen and using a census rather than a sample will improve the robustness of the data.

\subsection{Data Collection and Analysis}

The data used for this study was secondary data derived from financial statements of the listed deposit money banks in the Nigerian Stock Exchange (NSE) between the ten year period of 2005 and 2014. All companies listed on the NSE are required by law to submit financial report to the exchange every quarter. The information provided in these financial statements can be taken as reliable and comparable (Farroque, Ziji, Dunstan, \& Karin, 2007) Balanced panel data regression analysis was used in testing the three hypotheses while the Stata statistical package was employed for the data analysis.

Asokan, Iftekhar and Cornelia (2007) reported that most listed banks in Australia uses Loan Loss provisions to aggresively manage earnings, furthermore, Dabor and Ibadin (2013) used Abnormal Loan Loss Provisions (ABLL) as a proxy for earnings management where ABLL was measured as a modification of (Kanagaretnam, Krishnan, \& Lobo, 2010). Because loan loss provision is unique to the banking sector, it is expident to use abnormal loan loss provision in this study. The advantage of this method is that it is relatively easy to collect data in order to measure earnings management. The drawback however, is that earnings figures are just a part of the whole financial report and hence an indirect measure of reporting quality (Van Beest, Braam, \& Boelens, 2009). Despite this drawback, the framework for financial reporting (1989) has established that the most important aspect of financial report is the information on the entity's financial position and financial performance. This implies that the relevant aspect of the financial report to the primary users is the earnings figures, and once these figures have faithfully represented what it purports to represent. The primary qualitative characteristics of financial report would have been established (FASB, 2010). Hence, we observed that the determinants and consequences of abnormal accruals have received the most attention in previous studies. This tends to validate accrual models by showing that the abnormal accrual is correlated with hypothesized predicted determinants or consequence of abnormal accruals (Dechow' \& Ge, 2006). McNichols (2000) argued that the specific accrual model is the most appropriate for studies that are focused on industry settings in which a single accrual is sizable and requires substantial judgment. In line with Dabor and Ibadin (2013). Financial reporting quality is represented by abnormal loan loss provision which has been posited to be a function of structural variables (McNichols, 2000). This can be presented as follows;

$$
F R Q=f(F \text { Size, FAGE, LEV) }
$$

Since it is belived that there are also other variables that acts as determinant for financial reporting quality, board size, board independence, board gender mix and managerial shareholding were introduced as control variables. Hence,

$$
F R Q=\text { AFSize, FAGE, LEV, BSIZE, INDIR, FDIR, MS,IS) }
$$

With the aid of the second equation we can arrive at our model which is presented as follows;

$$
F R Q_{i t}=\beta_{0 i t}+\beta_{1} F S I Z E_{i t}+\beta_{2} F A G E_{i t}+\beta_{3} L E V_{i t}+\beta_{4} B S I Z E_{i t}+\beta_{5} I N D I R_{i t}+\beta_{6} F D I R_{i t}+\beta_{7} M S_{i t}+e_{i t}
$$

Where; FRQ = Financial Reporting Quality, $\beta_{0}$ is the intercept, $\beta_{1-7}$ is the coefficient of the independent variables, FSIZE $=$ Bank size which is measured as the asset size, FAGE $=$ The age of the bank measured as the year of incorporation; LEV $=$ Leverage measured as the percentage of debt finacing of the firm; BSIZE $=$ The size of the board measured as the number of board members, INDIR = Board Independence measured as the percentage of outside board memebers to the board size. FDIR = Percentage of female representation on the board, MS = Managerial Shareholding measured as the percentage of shares owned by top management to the total number of shares in issue, $\mathrm{e}=$ error term; $\mathrm{i}=$ firm; $\mathrm{t}=$ year

Financial reporting quality is measured by using Abnornal Loan Loss provision ABLL as a proxy for earnings management which is measured in line with (Kanagaretnam, Krishnan, \& Lobo, 2010; Dabor \& Ibadin, 2013) as;

$$
L L P=\alpha_{0}+\alpha_{1} L L A B+\alpha_{2} N P L A B+\alpha_{3} \Delta N P L+\alpha_{4} N B L W+\alpha_{5} \Delta T O T L+e_{t}
$$

The residual from equation four above are the abnormal loan loss provision where;

$\mathrm{NPLAB}=$ Non- Performing Loans at the beginning,

LLP $=$ Loan loss provisions, $\triangle \mathrm{NPL}=$ Change in Non-performing Loans, NBLW $=$ Net Bad Loans Written Off and $\triangle$ TOTL $=$ Change in Total Loan Loss 


\subsection{Robustness Test of Reliability and Validity}

A robustness test (multi-co-linearity, heteroscedasticity, cross-sectional dependence, serial correlation hausman specification and histogram test of residuals) were conducted in order to improve the validity of all statistical inferences for the study. VIF should not be greater than 10 and tolerance level 1; hence there is multi-co-linearity which means that the independent variable is related. This situation will make the F- Statistic and the $\mathrm{R}^{2}$ to be unreasonably high and hence affect the validity of the result. Durbin Watson will be used to test for serial correlation. A result of between 1.5 and 2.5 implies that there is no serial correlation. The hausman specification is what will indicate whether to interpret the fixed effect or the random effect of the chq-square.

\section{Data Analysis}

The use of regression model to estimate the coefficient of any panel data requires the determination of whether the fixed effect model or the random effect model suits the data more appropriately (Gujerati, Porter, \& Gunasekar, 2012) Fixed effect model takes into account the behavioural pattern of the firm but the random effect model does not consider the behavioural pattern of the firm. Table 4.1 below titled Hausman Statistics shows us the result obtained from our test.

Table 1. Hausman statistics

\begin{tabular}{ccccc}
\hline & & & Coefficients & \\
\hline & $(\mathrm{b})$ & $(\mathrm{B})$ & $(\mathrm{b}-\mathrm{B})$ & sqrt(diag(V_b-V_B $))$ \\
fsizeasset & fixed & random & Difference & S.E. \\
fage & .0597492 & .0053911 & .0543581 & .0292088 \\
lev & -.0106621 & .0008114 & -.0114735 & .0044588 \\
bsize & .2020423 & .0807311 & .1213112 & .0345292 \\
boardind & -.0076501 & -.0094315 & .0017814 & .0014062 \\
femaledirt $\sim \mathrm{e}$ & .0897275 & -.062865 & .1525925 & .0548994 \\
msharehold $\sim \mathrm{g}$ & .6234811 & .4405781 & .182903 & .033868 \\
\hline
\end{tabular}

Note. $\mathrm{b}=$ consistent under Ho and $\mathrm{Ha}$; obtained from xtreg

$\mathrm{B}=$ inconsistent under Ha, efficient under Ho; obtained from xtreg

Test: Ho: difference in coefficients not systematic

$\operatorname{chi} 2(7)=(b-B)^{\prime}\left[\left(V_{-} b-V \_B\right)^{\wedge}(-1)\right](b-B)=31.37$

Prob $>$ chi2 $=0.0001$

(V_b-V_B is not positive definite)

Source: Field work 2015 (Stata 12)

Table 1 shows that the p-value of the Hausman test is $0.0001<0.05$. Based on the rules of Hausman Statistics which state that if the p-value of the Hausman test is less than 0.05. Level of significance, the Hausman null is not accepted while we accept the Hausman alternate. The implication of this is that the fixed effect model is consistent with the data (Gujerati, Porter, \& Gunasekar, 2012). Therefore, this study adopted the fixed effect regression model.

The regression equation is reproduced as;

$$
F R Q_{i t}=\beta_{0 i t}+\beta_{1} F S I Z E_{i t}+\beta_{2} F A G E_{i t}+\beta_{3} L E V_{i t}+\beta_{4} B S I Z E_{i t}+\beta_{5} I N D I R_{i t}+\beta_{6} F D I R_{i t}+\beta_{7} M S_{i t}+e_{i t}
$$

Where; FRQ $=$ Financial Reporting Quality, $\beta_{0}$ is the intercept, $\beta_{1-3}$ is the coefficient of the independent variables that are to be estimated, $\beta_{4-7}$ is the coefficient of the control variables

FSIZE $=$ Size of firm $i$ in year $t$, FAGE $=$ The age of firm $i$ in year $t$, LEV $=$ Leverage of firm $i$ in year $t$, BSIZE $=$ The size of the board of firm $\mathrm{i}$ in year $\mathrm{t}$,INDIR $=$ Board Independence of firm $\mathrm{i}$ in year $\mathrm{t}$, FDIR $=$ Percentage of female representation on the board of firm $\mathrm{i}$ in year $\mathrm{t}, \mathrm{MS}=$ Managerial Shareholding of firm $\mathrm{i}$ in year $\mathrm{t}, \mathrm{e}=$ error term; $\mathrm{i}=$ firm, $\mathrm{t}=$ year 
Table 2. Fixed effects regression analysis

\begin{tabular}{|c|c|c|c|c|c|c|}
\hline \\
\hline \multicolumn{2}{|c|}{ Fixed-effects (within) regression } & \multicolumn{3}{|c|}{ Number of obs } & \multicolumn{2}{|c|}{130} \\
\hline \multicolumn{2}{|c|}{ Group variable: firms } & \multicolumn{3}{|c|}{ Number of groups } & \multicolumn{2}{|c|}{13} \\
\hline \multicolumn{2}{|c|}{ R-sq: within= 0.5999} & \multicolumn{3}{|c|}{ Obs per group: min } & \multicolumn{2}{|c|}{10} \\
\hline \multicolumn{2}{|c|}{ Between $=0.0589$} & \multicolumn{3}{|c|}{ avg } & \multicolumn{2}{|c|}{10.0} \\
\hline \multicolumn{2}{|c|}{ Overall $=0.0078$} & \multicolumn{3}{|c|}{$\max$} & \multicolumn{2}{|c|}{10} \\
\hline \multicolumn{2}{|c|}{-} & \multicolumn{3}{|c|}{$\mathrm{F}(7,12)$} & \multicolumn{2}{|c|}{71.88} \\
\hline \multicolumn{2}{|c|}{$\operatorname{corr}\left(\mathrm{u} \_\mathrm{i}, \mathrm{Xb}\right)=-0.9736$} & \multicolumn{3}{|c|}{ Prob> F } & \multicolumn{2}{|c|}{0.0000} \\
\hline \multicolumn{7}{|c|}{ Robust } \\
\hline Coef. & Std. Err. & $\mathrm{P}>\mathrm{t}$ & \multicolumn{4}{|c|}{ [95\% Conf. Interval] } \\
\hline fsizeasset & .0597492 & .0349098 & 1.71 & 0.113 & -.0163127 & .135811 \\
\hline fage & -.0106621 & .0057577 & -1.85 & 0.089 & -.0232071 & .0018829 \\
\hline lev & .2020423 & .2202458 & 0.92 & 0.377 & -.2778319 & 6819166 \\
\hline bsize & -.0076501 & .0037111 & -2.06 & 0.062 & -.0157359 & .0004356 \\
\hline boardind & .0897275 & .0562009 & 1.60 & 0.136 & -.0327237 & .2121787 \\
\hline femaledirtobsize & .6234811 & .1004585 & 6.21 & 0.000 & .4046008 & .8423615 \\
\hline mshareholding & .0003154 & .0031173 & 0.10 & 0.921 & -.0064766 & .0071073 \\
\hline _cons & -.2712482 & .2647532 & -1.02 & 0.326 & -.8480959 & .3055995 \\
\hline & sigma_u & & & & .36336383 & \\
\hline & sigma_e & & & & .06619727 & \\
\hline & rho & & & & .96787694 & \\
\hline
\end{tabular}

Source: Field work 2015 (Stata 12).

Table 2 reveals a summarized p-value of $0.0000<0.05$ significant levels indicating that the model is fit. This is further confirmed by the within coefficient of determination value of 0.5999 indicating that $59.99 \%$ of the variations within the banks are explained by the fixed effects model which contains three independent variable and 4 control variables. However, $40.01 \%$ of the variations within the banks are unexplained by the model. The table further shows that the only variable with a p-value that is significant at 0.05 significant levels is female directors on the board with 0.000 while, firm age and board size are significant at 0.1 significant levels. The table also shows that between the deposit money banks, the variations can only be explained by coefficient of determination value of 0.0589 and over all coefficient of determination value of 0.0078 .

The $40.01 \%$ of the unexplained variations can be attributed to other variables such as special features of these firms like managerial style, and other micro economic variables that could affect the reporting quality of the banks.

Table 3. Variance inflation factor

\begin{tabular}{ccc}
\hline Variable & VIF & 1/VIF \\
\hline bsize & 1.39 & 0.717330 \\
lev & 1.37 & 0.732336 \\
fsizeasset & 1.34 & 0.746203 \\
fage & 1.21 & 0.824964 \\
boardind & 1.18 & 0.845628 \\
msharehold g & 1.07 & 0.937423 \\
femaledirt e & 1.05 & 0.949486 \\
Mean VIF & 1.23 & \\
\hline
\end{tabular}

Source: Field work 2015 (Stata 12).

In order to assess the presence of multicollinearity, the study further conducted a multicollinearty test, using Variance Inflation Factor (VIF) and its reciprocal (1/VIF). The benchmark for VIF is that at 5\%, collinearity is suspected; at over $10 \%$, collinearity is assumed to be present. The result suggests absent of multicollinearity. This can be confirmed from the statistical result that shows all the VIF and 1/VIF are above 1 and less than 1 respectively, while the mean value of VIF is 1.23 as shown in table 3 above. All these suggest absence of multicollinearity. 
The robust standard error known as corrected standard error in table 2 has also made adjustments for the heteroscedasticity and auto correlation consistent hence it is called HAC standard errors.

Table 4. OLS regression result

\begin{tabular}{cccccccc}
\hline Source & SS & df & MS & Number of obs & 130 \\
Model & .703007244 & 7 & .100429606 & Prob > F & 0.0000 \\
Residual & .61581496 & 122 & .005047664 & R-squared & 0.5331 \\
& & \multicolumn{7}{c}{ Adj R-squared =0.5063 } \\
Total & 1.3188222 & 129 & .010223428 & Root MSE & .07105 \\
& Abll Coef. & Std. Err. & $\mathrm{t} \quad$ P>t & [95\% Conf. Interval] \\
fsizeasset & .0053911 & .0160573 & 0.34 & 0.738 & -.0263959 & .037178 \\
fage & .0008114 & .0002245 & 3.61 & 0.000 & .0003669 & .0012558 \\
lev & .0807311 & .0839038 & 0.96 & 0.338 & -.0853649 & .2468271 \\
bsize & -.0094315 & .0021764 & -4.33 & 0.000 & -.0137399 & -.0051232 \\
boardind & -.062865 & .0638198 & -0.99 & 0.327 & -.1892026 & .0634726 \\
femaledirtobsize & .4405781 & .0411848 & 10.70 & 0.000 & .3590486 & .5221076 \\
mshareholding & -.0008628 & .0050157 & -0.17 & 0.864 & -.0107919 & .0090662 \\
cons & .0489137 & .1900409 & 0.26 & 0.797 & -.3272912 & .4251186 \\
\hline
\end{tabular}

Source: Field work 2015 (Stata 12).

Table 4 reveals a summarized p-value of $0.0000<0.05$ significant levels indicating that the model is fit. This is also further confirmed by the coefficient of determination value of 0.5331 indicating that $53.31 \%$ of the variations are explained by the model which contains three independent variable and 4 control variables. The unexplained $46.69 \%$ of the variations is attributable to the error term of the model.

\subsection{Interpretation of Regression Results}

The regression result is interpreted below base on each hypothesis stated in their null form using table 2 above.

The first hypothesis states that there is a significant relationship between firm size and financial reporting quality of listed deposit money banks in Nigeria. From Table 2 above, a p-value of 0.113 suggests that we fail to reject the null hypothesis. Even though there is a positive relationship of 0.5975 with abnormal loan loss, the relationship is not significant at $0.5 \%$ level of significance. Hence we conclude that there is no significant relationship between firm size and financial reporting quality of listed deposit money banks in Nigeria. It should however be noted that a positive relationship with abnormal loan loss implies a negative relationship with financial reporting quality.

The second hypothesis states that there is a significant relationship between leverage and financial reporting quality of listed deposit money banks in Nigeria. From Table 2, the relationship between leverage and financial reporting quality of listed deposit money banks in Nigeria is put at 0.2020 however; this is also not significant at a p-value of 0.377 at a $5 \%$ level of significance. The implication of this also is that we shall fail to reject the null hypothesis and conclude that there is no significant relationship between leverage and financial reporting quality of listed deposit money banks in Nigeria.

The third hypothesis states that there is a significant relationship between firm age and financial reporting quality of listed deposit money banks in Nigeria. From Table 2, the relationship between firm age and financial reporting quality is a positive one since it has a negative relationship with abnormal loan loss. The extent of this relationship is put at -0.1066 at a p-value of 0.089 . This is also not significant at $5 \%$ level of significance thought it is significant at $10 \%$. The study therefore also shall fail to reject the null hypothesis and conclude that there is no significant relationship between firm age and financial reporting quality of listed deposit money banks in Nigeria.

\subsection{Discussion of Findings}

The first hypothesis was set up to establish whether or not there was a significant relationship between firm size and financial reporting quality of listed deposit money banks in Nigeria. Our findings are that there is no significant relationship between firm size and financial reporting quality. A p-value of 0.113 is indicative of the fact that the association can only be significant at $15 \%$. A positive relationship of 0.5975 with abnormal loan loss 
shows that the bigger the firm the more the abnormal loan loss provision and the lower the quality of the financial report. However, since this relationship is at $0.113>0.05$, we draw the conclusion that there is no significant relationship between the two variables. Further, in consideration of one of the objectives of the study, the effect of the size of listed deposit money banks in Nigeria on the quality of their financial reports can be said to be insignificantly negative. On a final note, and in order to give answers to the first research question we can establish that the relationship between firm size and the quality of their financial reports is a negative one.

This finding is in tandem with the findings of Missonier-Piera (2004) and Thoopsamut and Jaikengkit (2009). These studies posit that company size is not significantly related to financial reporting quality although their work was not conducted in an emerging economy like Nigeria. This finding is also in line with Waweru and Riro, (2013) who established that company size is not significantly related to financial reporting quality. Other studies that are consistent with our finding were carried out by Missonier-Piera 2004 and Thoopsamut and Jaikengkit (2009). However, the finding of this work is inconsistent with that of Shehu and Ahmad (2013) who posited that large firms have very strong reasons to manipulate their earnings in order to keep consistent earnings growth trend and meet and beat earnings expectations, they documented that firm size has significant effect on earnings quality. Other studies with findngs that are contrary to our findings are (Becker, DeFoond, Jiambalvo, \& Subramanyam, 1998). The reasons for these divergent findings may not be unconnected with the fact that most of these studies were not carried out in an emerging econonmy and for the study conducted by Shehu and Ahmad (2013), the focus was in the manufacturing industry.

The findings in this current study is quite important as it has shown that as it concerns the deposit money banks, eventhough there is a negative relationship between firm size and financial reporting quality, the relationship is quite insignificant. The implication of this to the regulators and other stake holders is for them to now focus on other characteristics that are significantly related to financial reporting quality.

The objective of the second hypothesis is to establish whether or not there is a significant relationship between leverage and financial reporting quality of listed deposit money banks in Nigeria. This relationship is put at 0.2020 however; this is also not significant at a p-value of $0.377>0.05$. Hence, we concluded that there is no significant relationship between leverage and financial reporting quality of listed deposit money banks in Nigeria. The relevant objective to this hypothesis is to examine the impact of debt financing on financial reporting quality of listed deposit money banks in Nigeria. The finding has shown that the impact is very weak and quite insignificant. Hence the level to which the leverage of listed deposit money banks in Nigeria affects their financial reporting quality is negative 20 percent at a p-value of 0.377 .

The finding of this current work is in line with those of (Wallace, Naser, \& Mora 1994; Owusu-Ansah, 1998; Nedal, Bana, \& David, 2010), who did not find any significant positive relationship between leverage and financial reporting quality. But inconsistent with Waweru and Riro (2013) who asserts that highly leverage firms are more likely to engage in earnings management than firms that are not highly leveraged. Shehu 2013 and Shehu \& Ahmad 2013 also established a significant relationship between the degree of leverage and the level of earnings management in contrast to our finding. Reasons for this variation could also be possibly explained by the difference in economy, period and timing of study and the specific industrial differences.

The implication of this finding is that leverage is negatively and insignificantly related to financial reporting quality. Which means that increasing gearing will negatively impact though insignificantly on the financial reporting quality. This is because the regression result indicates a positive relationship between leverage and abnormal loan loss provision and increasing abnormal loan loss provision is an indication of earnings management whereas earninings management is negatively related to financial reporting quality. In as much as debt financing is likely to enhance the firms value, it is also capable of exposing the firm to the risk of liquidation or take over, managers should therefore find the optimal point for substainable development.

Hypothesis 3 was designed to establish whether or not there is a significant relationship between firm age and financial reporting quality of listed deposit money banks in Nigeria. The finding of the study reveals that the relationship between firm age and financial reporting quality is a positive one since it has a negative relationship with abnormal loan loss. The extent of this relationship is put at -0.1066 at a p-value of 0.089 . Although not significant at $5 \%$ level of significance it is significant at $10 \%$. Hence, our decision not to reject the null hypothesis and our conclusion that there is no significant relationship between firm age and financial reporting quality of listed deposit money banks in Nigeria. In answering our research question, the association between the age of listed deposit money banks in Nigeria and the quality of their financial report is a positive one which means that the older the firms, the better the quality of their financial statement.

The finding is in line with Chalaki, Didarand Riahnezhad (2012) and Huang, Rose-Green and Lee (2012), their 
studies established that there is no significant relationship between firm age and finanacial reporting quality. Eventhough our finding has show an insignificant positive relationship between firm age and financial reporting quality, the positive relationship is significant at $10 \%$ level of significance. Hence stake holders and regulator should expect the financial reports of a firm to improve over time because the internal control of such firms are expected to become better structured with time and a strong internal control is associated with financial reporting quality (Huang, Rose-Green, \& Lee, 2012).

\subsection{Recommendations}

Since the relationship between firm size and financial reporting quality is negative though insignificant, which imply that the bigger the bank the lower the quality of the financial reports. The study will recommend for shareholders and financial analyst to always make provisions for this when doing interbank analysis. A negative relationship between leverage and financial reporting quality suggest that the higher the level of leverage the lower the quality of the financial report. Even though this relationship is not significant, the study will like to recommend that the apex bank give a leverage ceiling for banks based on certain parameter such as asset size, deposit base and so on especially for those banks borrowing from other country in other currencies which also introduces foreign exchange risk. The relationship between firm age and financial reporting quality is insignificantly positive at 5\% level of significance but significantly positive at $10 \%$ level of significance, this suggests that the older the firm the better the quality of their financial statement. The study will therefore like to recommend that the apex bank prescribe a minimum standard for the internal control of deposit money banks in Nigeria so that both new and old banks will achieve a minimum level of quality in their financial reporting practices.

\section{Conclusion}

The study covers thirteen out of the fifteen listed deposit money banks in Nigeria as at the financial year ended 2014 and determines the relationship between firm structural attributes and financial reporting quality. Based on our finding from the regression result and the test of hypotheses 1,2 and 3.

Hypothesis 1 sought to examine the relationship between firm size and financial reporting quality of listed deposit money banks in Nigeria and further to determine how significant this relationship is. Based on our finding, we conclude that firm size is not a significant factor that determines the quality of financial reports although there is an insignificant negative relationship. Hypothesis 2 focused on determining the relationship between the level of leverage in Nigeria banks and financial reporting quality. Based on our findings we conclude that leverage is not a significant determinant of financial reporting quality in the Nigerian banking industry although there is an insignificant negative relationship. Hypothesis 3 aimed at evaluating whether or not firm age is a determinant of financial reporting quality of listed deposit money banks in Nigeria. The result obtained from this study as shown in table 2 assisted us to conclude that firm age is only positively significantly related to financial reporting quality at $10 \%$ level of significance and not at $5 \%$, hence, firm age is positively related to financial reporting quality although the relationship is insignificant.

The overall conclusion of the study therefore is that firm structural characteristics have no significant relationship with financial reporting quality of listed deposit money banks in Nigeria.

\section{References}

Asokan, A., Iftekhar, H., \& Cornelia, M. (2007). Use of Loan Loss Provisions for Capital, Earnings Management and Signalling by Austrialian Banks. Journal of Accounting and Finance, 47(3), 357-379. http://dx.doi.org/10.1111/j.1467-629X.2007.00220.x

Bekcker, C., DeFoond, M., Jiambalvo, J., \& Subramanyam, K. R. (1998). The Effect of Audit Quality on Earnings Management. Contemporary Accounting Research, 15(1), 1-24. http://dx.doi.org/10.1111/j.1911-3846.1998.tb00547.x

Cbn Prudential Guidlines. (2010). Publication/Bsd/Prudential Guidlines. Retrieved from http://www.cenbank.org

Chalaki, P., Didar, H., \& Riahnezhad, M. (2012). Corporate Governance Attributes and Financial Reporting Quality: Empirical Evidence from Iran. International Journal of Business and Soicial Science, 3(15), 223-229.

Chen, Q., \& Jaggi, A. (2007). Finanacial Accounting Information, Organational Complexities and Corporate Governance Systems. Journal of Accounting and Economics, 37(2), 167-201.

Dabor, E. L., \& Ibadin, P. O. (2013). An Evaluation of the Implications of Earnings Management Determinants 
In the Banking Industry: The Case of Nigeria. Afican Journal of Social Sciences, 3(3), 118-129.

Dechow, P., \& Dichev, I. (2002). The Quality of Accruals and Earnings: The Role of Accrual Estimation Errors. The Accounting Review, 77, 35-59. http://dx.doi.org/10.2308/accr.2002.77.s-1.35

Dechow, P., \& Ge, W. (2006). The persistence of earnings and cash flows and the role of special items:Implications for the accrual anomaly. Review of Accounting Studies, 11, 253-296. http://dx.doi.org/10.1007/s11142-006-9004-1

Farroque, O. A., Ziji, T. V., Dunstan, K., \& Karin, A. W. (2007). Corporate Governance in Bangladesh: Link between Ownership and Financial Performance. BRAC University Journal of Corporate Governance, $15-29$.

FASB. (2010). Conceptual Framwor for Financial Reporting: The Objective of Financial Reporting and Qualitative Characteristics of Useful Financial Information. Norwalk, Connecticut: Financial Accounting Foundation.

Gujerati, D. N., Porter, D. C., \& Gunasekar, S. (2012). Basic econometrics (5th ed.). New Delhi: Tata McGraw Hill Education Limited.

Huang, H. W., Rose-Green, E., \& Lee, C. C. (2012). CEO Age and Financial Reporting Quality. Accounting Horizons, 26(4), 725-740. http://dx.doi.org/10.2308/acch-50268

IASB. (2008). Exposure Draft on an improved Conceptual Framwork for Financial Reporting: The Objective of Financial Reporting and Qualitative Characteristics of Decision-useful Financial Reporting Information. London: IASB.

Jensen, M. C., \& Meckling, W. H. (1976). The Theory of the firm;Managerial behaviour, Agency Costs, and $\begin{array}{lllll}\text { Ownership Structure. Journal of Financial Economics, 11(4), 305-360. } & \text {. }\end{array}$ http://dx.doi.org/10.1016/0304-405X(76)90026-X

Kamaruzaman, A. J., Mazilifa, M. D., \& Maisarah, A. R. (2009). The Association between Firm Characteristics and Financial Statements Transparency; The Case of Egypt. International Journal of Accounting, 18(2), 211-223.

Kanagaretnam, K., Krishnan, G. V., \& Lobo, G. J. (2010). An Empirical Analysis of Auditors Independence in the Banking Industry. The Accounting Review, 85(6), 2011-2046. http://dx.doi.org/10.2308/accr.2010.85.6.2011

Maimako, S. S., \& Oladele, O. K. (2008). Risk Dimensions in Business Processes in Nigeria; A Comparative Study of The Nigerian Banking and Insurance Sub-Sector between 1999 and 2006. International Conference on Marketing (pp. 11-21). Jos: Department of Management Sciences,University of Jos.

Maharshi, D. U. (2004). Accounting theory. Naraina, Phase 1, New Delhi-110028: ROHTAK. 124001 EXCEL BOOKS PVT. LTD., A-45.

Martinez-Ferrero, J. (2014). Consequences of Financial Reporting Quality on Corporate Performance; Evidence $\begin{array}{lllll}\text { at International Level. Estudios de } & \text { Economia, 41(1), }\end{array}$ http://dx.doi.org/10.4067/S0718-52862014000100002

McNichols, M. F. (2000). Research design issues in earnings management studies. Journal of Accounting and Public Policy, 19, 313-345. http://dx.doi.org/10.1016/S0278-4254(00)00018-1

Missonier-Piera, F. (2004). Economic Determinants of Multiple Accounting Mrthod Choices in Swiss Context. Journal of International Financial Management and Accounting, 15(2), 119-144. http://dx.doi.org/10.1111/j.1467-646X.2004.00104.x

Nedal, A., Bana, A., \& David, A. (2010). Ownership Structure and Earnings Management in Earnings Markets: A case of Jordan. Jornal of Finance and Economics, 3(2), 1-20.

Okwoli, A. A. (2009). Principles of financial accounting. Jos: Go-Go International.

Owusu-Ansah, S. (1998). The Impact of Firm Characteristics on the Extent of Mandatory Disclosure and Reporting by Listed Firms in Zimbabwe. International Journal of Accounting, 33(5), 605-626. http://dx.doi.org/10.1016/S0020-7063(98)90015-2

Saheed, Z. (2013). Impact of Globalisation on Corporate Governance in Developing Economy; A Theoretical Approach. Journal of Business and Management, 2(1), 1-10. http://dx.doi.org/10.12735/jbm.v2i1p01

Shehu, \& Ahmad. (2013). Firm Characteristics and Financial Reporting Quality of Listed Manufacturing Firms 
in Nigeria. Internantional Journal of Accounting, Banking and Management, 1(6), 47-63.

Shehu, U. H. (2013). Financial Reporting Quality, Does Monitoring Characteristics Matter? An Empirical Analysis of Nigerian Manufacturing Sector. The Business \& Management Review, 3, 147-161.

Thoopsamut, W., \& Jaikengkit, A. (2009). Audit Committee Characteristics, Audit Firm Size and Quarterly Earnings Management in Thailand. Oxford Journal, 8(1), 3-12.

Valipour, H., \& Moradbeygi, M. (2011). Corporate Debt Financing and Earnings Quality. Journal of Applied Finance \& Banking, 1(3), 139-157.

Van Beest, F., Braam, G., \& Boelens, S. (2009). Quality of Financial Reporting: Mdasuring Qualitative Characteristics. Nijmegen Center of Economics Working Paper, 09-108.

Wallace, R. S., Naser, K., \& Mora, A. (1994). The Relationship between Comprehensiveness of Corporate annual reports and firm Characteristics in Spain. Accounting and Business Resaerch, 25(97), 41-53. http://dx.doi.org/10.1080/00014788.1994.9729927

Wallace, R. S. (1988). Corporate Financial Reporting in Nigeria. Accounting and Business Research, 18(72), 352-362. http://dx.doi.org/10.1080/00014788.1988.9729382

Waweru, N. M., \& Riro, G. K. (2013). Corporate Governance, Firm Characteristics and Earnings Management in an Emerging Economy. Journal of Accounting Research, 11(1), 43-64.

\section{Appendix 1}

Summary of empirical reviews

\begin{tabular}{|c|c|c|c|c|c|c|c|c|}
\hline $\begin{array}{l}\text { NAME OF } \\
\text { AUTHOUR }\end{array}$ & DATE & $\begin{array}{l}\text { JOURNAL } \\
\text { NAME }\end{array}$ & PUBLISHER & $\begin{array}{c}\text { TITLE OF } \\
\text { PUBLICATION }\end{array}$ & RESEARCH METHOD & $\begin{array}{c}\text { Independent } \\
\text { Variable }\end{array}$ & $\begin{array}{c}\text { RESEARCH } \\
\text { QUESTIONS/HYPOTHESES }\end{array}$ & FINDINGS \\
\hline $\begin{array}{l}\text { Waweru } \\
\& \text { Riro, }\end{array}$ & 2013 & $\begin{array}{l}\text { Journal of } \\
\text { Accounting } \\
\text { Research }\end{array}$ & $\begin{array}{l}\text { University } \\
\text { of Chicago } \\
\text { on behalf of } \\
\text { the Institute } \\
\text { of } \\
\text { Professional } \\
\text { Accounting }\end{array}$ & $\begin{array}{c}\text { Corporate } \\
\text { Governance, Firm } \\
\text { Characteristics } \\
\text { and Earnings } \\
\text { Management in an } \\
\text { Emerging } \\
\text { Economy }\end{array}$ & $\begin{array}{c}\text { Multiple regression } \\
\text { analysisACCURAL/EARNI } \\
\text { NGS MGT }\end{array}$ & Leverage & $\begin{array}{c}\text { Leverage does not } \\
\text { significantly affect financial } \\
\text { reporting quality }\end{array}$ & $\begin{array}{l}\text { financial } \\
\text { reporting of } \\
\text { firms that } \\
\text { are lowly } \\
\text { geared are } \\
\text { of better } \\
\text { quality }\end{array}$ \\
\hline Shehu & 2013 & $\begin{array}{l}\text { The Business } \\
\text { and } \\
\text { Management } \\
\text { Review }\end{array}$ & $\begin{array}{l}\text { Global } \\
\text { Research } \\
\text { Society }\end{array}$ & $\begin{array}{c}\text { Financial } \\
\text { Reporting Quality, } \\
\text { Does Monitoring } \\
\text { Characteristics } \\
\text { Matter? An } \\
\text { Epirical Analysis } \\
\text { of Nigerian } \\
\text { Manufacturing } \\
\text { Sector }\end{array}$ & $\begin{array}{c}\text { Multiple regression } \\
\text { analysis/ACCURAL/EARNI } \\
\text { NGS MGT, Modified } \\
\text { Dechow and Dichev's } 2002 \\
\text { model }\end{array}$ & Leverage & $\begin{array}{c}\text { Does Monitoring } \\
\text { Characteristics affect } \\
\text { financial reporting quality? }\end{array}$ & $\begin{array}{c}\text { There is a } \\
\text { significant } \\
\text { positive } \\
\text { relationship } \\
\text { between } \\
\text { monitoring } \\
\text { characteristics } \\
\text { and financial } \\
\text { reporting } \\
\text { quality }\end{array}$ \\
\hline $\begin{array}{c}\text { Farrell, } \\
\text { Yu, \& } \\
\text { Zhang }\end{array}$ & 2013 & $\begin{array}{c}\text { Corporate } \\
\text { Governance;An } \\
\text { International } \\
\text { Review }\end{array}$ & $\begin{array}{l}\text { John Wiley } \\
\& \text { Sons Ltd }\end{array}$ & $\begin{array}{c}\text { What are the } \\
\text { Characteristics of } \\
\text { Firms that Engage } \\
\text { in Earnings per } \\
\text { Shares } \\
\text { Management } \\
\text { Through Share } \\
\text { Repurchases? }\end{array}$ & Multiple regression & Leverage & $\begin{array}{l}\text { High leverage firms are less } \\
\text { likely to enagege in EPS } \\
\text { management through share } \\
\text { repurchase. }\end{array}$ & $\begin{array}{c}\text { High } \\
\text { leverage } \\
\text { firms are } \\
\text { more likely } \\
\text { to manage } \\
\text { their } \\
\text { earnings } \\
\text { per shares }\end{array}$ \\
\hline $\begin{array}{l}\text { Valipour \& } \\
\text { Moradbeygi }\end{array}$ & 2011 & $\begin{array}{c}\text { Journal of } \\
\text { Applied } \\
\text { Finanace and } \\
\text { Banking }\end{array}$ & $\begin{array}{l}\text { Scienpress } \\
\text { Ltd }\end{array}$ & $\begin{array}{l}\text { Corporate Debt } \\
\text { Financing and } \\
\text { Earnings Quality }\end{array}$ & Multiple regression analysis & Leverage & $\begin{array}{l}\text { There is no relationship } \\
\text { between earnings quality and } \\
\text { corporate debt financing }\end{array}$ & $\begin{array}{l}\text { The reported } \\
\text { a negative } \\
\text { and } \\
\text { meaningful } \\
\text { relationship } \\
\text { between debt } \\
\text { and earning } \\
\text { quality }\end{array}$ \\
\hline $\begin{array}{c}\text { Nallace, R S; } \\
\text { Naser, k; }\end{array}$ & 1994 & $\begin{array}{l}\text { Accounting } \\
\text { and Business }\end{array}$ & Researchgate & $\begin{array}{l}\text { The relationship } \\
\text { between }\end{array}$ & Multiple regression analysis & Leverage & $\begin{array}{c}\text { Leverage does not } \\
\text { significantly affect financial }\end{array}$ & $\begin{array}{l}\text { There is no } \\
\text { significant }\end{array}$ \\
\hline
\end{tabular}




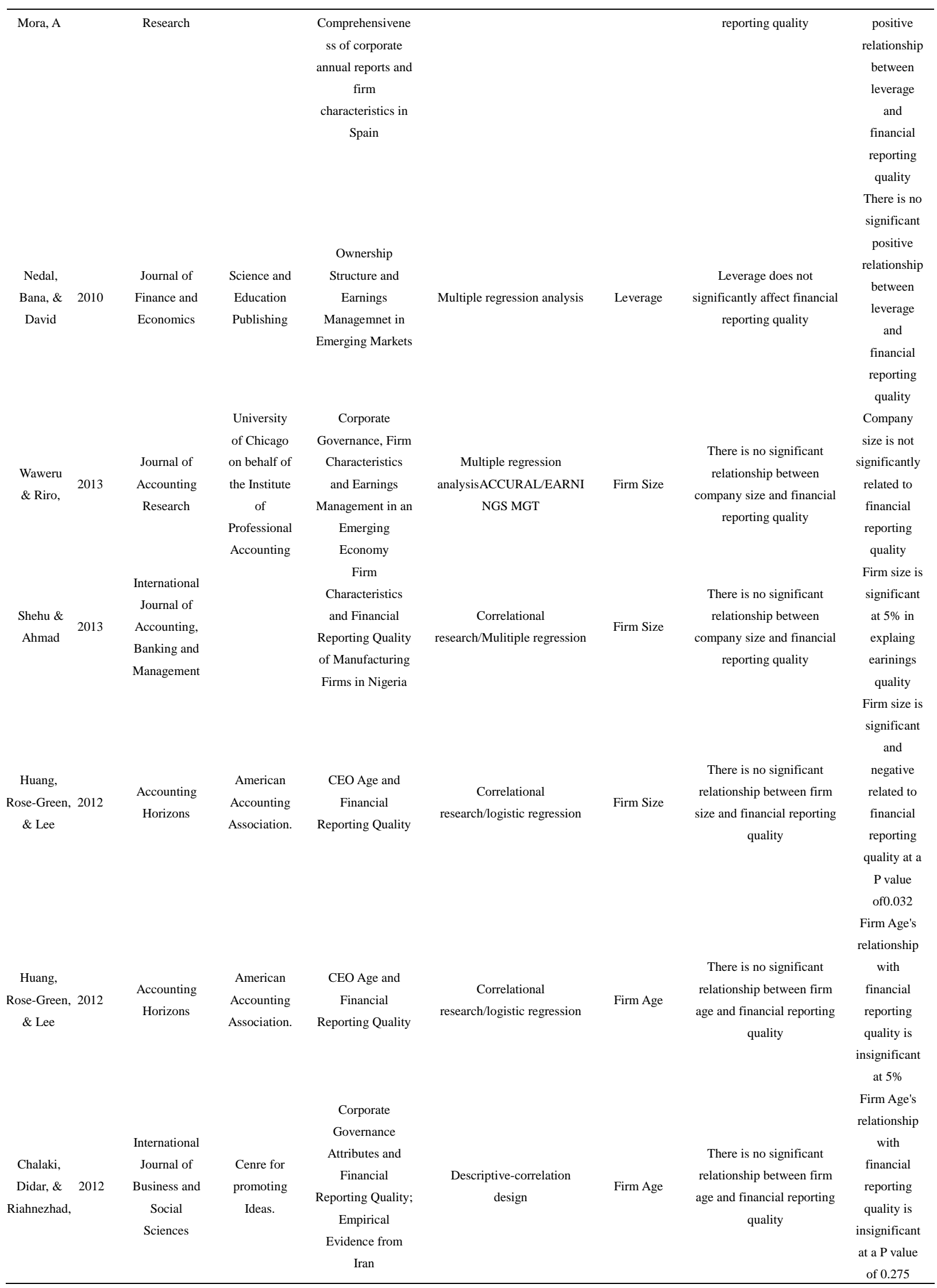

Source; Authour's Compilation 2015 


\section{Appendix 2}

Definition of measurement variables

\begin{tabular}{|c|c|c|c|c|c|}
\hline Variables & $\begin{array}{l}\text { Variable } \\
\text { Attribute }\end{array}$ & Variable Type & Definition & Measurement & Source \\
\hline ABLL & $\begin{array}{l}\text { Not } \\
\text { Applicable }\end{array}$ & Dependent & $\begin{array}{l}\text { Abnormal Loan Loss } \\
\text { provision }\end{array}$ & $\begin{array}{l}\text { Difference between total } \\
\text { loan loss and normal loan } \\
\text { loss }\end{array}$ & $\begin{array}{l}\text { (Kanagaretnam, Krishnan, \& } \\
\text { Lobo, 2010), (Dabor \& } \\
\text { Ibadin, 2013) }\end{array}$ \\
\hline FSIZE & Structural & Independent & The size of the bank & Natural log of total assets & $\begin{array}{l}\text { (Gerayli, Yanesari, \& } \\
\text { Ma'atoofi, 2011) }\end{array}$ \\
\hline FAGE & Structural & Independent & The age of the banks. & $\begin{array}{l}\text { Number of years the banks } \\
\text { have been in business }\end{array}$ & $\begin{array}{l}\text { (Chalaki, Didar, \& } \\
\text { Riahnezhad, 2012) }\end{array}$ \\
\hline LEV & Structural & Independent & Leverage/gearing ratio & $\begin{array}{l}\text { Total debt X } 100 \\
\text { Shareholders fund }\end{array}$ & $\begin{array}{l}\text { (Shehu \& Ahmad, 2013) and } \\
\text { CBN prudential Guideline, } \\
2010\end{array}$ \\
\hline
\end{tabular}

Source; Author's compilation, 2015

\section{Appendix 3}

Structural characteristics data

\begin{tabular}{|c|c|c|c|c|c|c|c|c|c|}
\hline BANK & YEAR & ABLL & F SIZE (ASSET) & F AGE & LEV & B SIZE & $\begin{array}{c}\text { BOARD } \\
\text { IND }\end{array}$ & $\begin{array}{c}\text { FEMALE } \\
\text { DIR TO } \\
\text { B SIZE }\end{array}$ & $\begin{array}{l}\text { M SHARE } \\
\text { HOLDING }\end{array}$ \\
\hline \multirow[t]{10}{*}{ ACCESS } & 2005 & 0.01 & 10.83 & 16.00 & 0.25 & 8.00 & 0.63 & 0.00 & 14.73 \\
\hline & 2006 & 0.02 & 11.24 & 17.00 & 0.14 & 12.00 & 0.58 & 0.00 & 0.10 \\
\hline & 2007 & 0.01 & 11.61 & 18.00 & 0.20 & 12.00 & 0.58 & 0.00 & 0.19 \\
\hline & 2008 & 0.01 & 12.02 & 19.00 & 0.41 & 14.00 & 0.57 & 0.07 & 0.13 \\
\hline & 2009 & 0.04 & 11.81 & 20.00 & 0.05 & 14.00 & 0.57 & 0.07 & 0.14 \\
\hline & 2010 & 0.02 & 11.86 & 21.00 & 0.06 & 14.00 & 0.57 & 0.07 & 0.11 \\
\hline & 2011 & 0.02 & 11.98 & 22.00 & 0.06 & 14.00 & 0.57 & 0.14 & 0.13 \\
\hline & 2012 & 0.02 & 12.18 & 23.00 & 0.03 & 14.00 & 0.57 & 0.14 & 0.13 \\
\hline & 2013 & 0.01 & 12.23 & 24.00 & 0.03 & 15.00 & 0.53 & 0.33 & 0.07 \\
\hline & 2014 & 0.02 & 12.30 & 25.00 & 0.07 & 16.00 & 0.56 & 0.31 & 0.07 \\
\hline \multirow[t]{10}{*}{ DIAMOND } & 2005 & 0.01 & 11.12 & 15.00 & 0.05 & 14.00 & 0.57 & 0.00 & 0.15 \\
\hline & 2006 & 0.01 & 11.35 & 16.00 & 0.04 & 14.00 & 0.57 & 0.00 & 0.13 \\
\hline & 2007 & 0.01 & 11.49 & 17.00 & 0.03 & 14.00 & 0.57 & 0.00 & 0.21 \\
\hline & 2008 & 0.01 & 11.78 & 17.00 & 0.03 & 14.00 & 0.57 & 0.00 & 0.08 \\
\hline & 2009 & 0.03 & 11.81 & 18.00 & 0.04 & 14.00 & 0.57 & 0.00 & 0.08 \\
\hline & 2010 & 0.03 & 11.74 & 19.00 & 0.05 & 14.00 & 0.64 & 0.14 & 0.08 \\
\hline & 2011 & 0.07 & 11.86 & 20.00 & 0.08 & 16.00 & 0.63 & 0.13 & 0.23 \\
\hline & 2012 & 0.04 & 12.07 & 22.00 & 0.06 & 16.00 & 0.63 & 0.19 & 0.24 \\
\hline & 2013 & 0.01 & 12.13 & 23.00 & 0.05 & 20.00 & 0.60 & 0.15 & 0.23 \\
\hline & 2014 & 0.01 & 12.24 & 24.00 & 0.06 & 13.00 & 0.62 & 0.15 & 0.14 \\
\hline \multirow[t]{9}{*}{ ECOBANK } & 2005 & 0.01 & 10.83 & 17.00 & 0.13 & 6.00 & 0.33 & 0.17 & 0.02 \\
\hline & 2006 & 0.01 & 10.83 & 18.00 & 0.13 & 12.00 & 0.67 & 0.08 & 0.02 \\
\hline & 2007 & 0.02 & 11.49 & 19.00 & 0.13 & 11.00 & 0.73 & 0.18 & 0.01 \\
\hline & 2008 & 0.03 & 11.64 & 20.00 & 0.05 & 11.00 & 0.73 & 0.18 & 0.01 \\
\hline & 2009 & 0.02 & 11.55 & 21.00 & 0.06 & 15.00 & 0.60 & 0.40 & 0.00 \\
\hline & 2010 & 0.03 & 11.66 & 22.00 & 0.01 & 15.00 & 0.60 & 0.27 & 0.00 \\
\hline & 2011 & 0.26 & 12.04 & 23.00 & 0.06 & 15.00 & 0.60 & 0.27 & 0.00 \\
\hline & 2012 & 0.01 & 12.12 & 23.00 & 0.04 & 15.00 & 0.60 & 0.27 & 0.00 \\
\hline & 2013 & 0.02 & 12.16 & 24.00 & 0.04 & 17.00 & 0.53 & 0.24 & 0.00 \\
\hline
\end{tabular}




\begin{tabular}{|c|c|c|c|c|c|c|c|c|c|}
\hline & 2014 & 0.08 & 12.25 & 25.00 & 0.08 & 15.00 & 0.53 & 0.20 & 0.00 \\
\hline \multirow[t]{10}{*}{ FIDELITY } & 2005 & 0.02 & 10.54 & 18.00 & 0.05 & 13.00 & 0.69 & 0.08 & 0.01 \\
\hline & 2006 & 0.02 & 11.08 & 19.00 & 0.08 & 14.00 & 0.64 & 0.07 & 0.09 \\
\hline & 2007 & 0.01 & 11.34 & 20.00 & 0.05 & 13.00 & 0.69 & 0.08 & 0.06 \\
\hline & 2008 & 0.01 & 11.73 & 21.00 & 0.03 & 13.00 & 0.69 & 0.08 & 0.06 \\
\hline & 2009 & 0.04 & 11.70 & 22.00 & 0.03 & 13.00 & 0.62 & 0.15 & 0.04 \\
\hline & 2010 & 0.02 & 11.68 & 23.00 & 0.02 & 19.00 & 0.63 & 0.16 & 0.05 \\
\hline & 2011 & 0.01 & 11.87 & 24.00 & 0.02 & 17.00 & 0.59 & 0.18 & 0.05 \\
\hline & 2012 & 0.02 & 11.96 & 25.00 & 0.03 & 16.00 & 0.63 & 0.19 & 0.04 \\
\hline & 2013 & 0.01 & 12.03 & 26.00 & 0.03 & 16.00 & 0.63 & 0.19 & 0.04 \\
\hline & 2014 & 0.01 & 12.07 & 27.00 & 0.10 & 14.00 & 0.50 & 0.21 & 0.05 \\
\hline \multirow[t]{10}{*}{ FIRST BANK } & 2005 & 0.05 & 11.67 & 111.00 & 0.17 & 14.00 & 0.57 & 0.07 & 0.05 \\
\hline & 2006 & 0.01 & 11.73 & 112.00 & 0.06 & 20.00 & 0.65 & 0.05 & 0.04 \\
\hline & 2007 & 0.01 & 11.88 & 113.00 & 0.09 & 15.00 & 0.53 & 0.07 & 0.01 \\
\hline & 2008 & 0.01 & 12.07 & 114.00 & 0.03 & 15.00 & 0.53 & 0.07 & 0.13 \\
\hline & 2009 & 0.21 & 12.25 & 115.00 & 0.02 & 16.00 & 0.63 & 0.19 & 0.02 \\
\hline & 2010 & 0.04 & 12.29 & 116.00 & 0.06 & 16.00 & 0.63 & 0.19 & 0.02 \\
\hline & 2011 & 0.13 & 12.46 & 117.00 & 0.04 & 6.00 & 0.83 & 0.00 & 0.02 \\
\hline & 2012 & 0.21 & 12.50 & 118.00 & 0.02 & 6.00 & 0.83 & 0.00 & 0.02 \\
\hline & 2013 & 0.15 & 12.59 & 119.00 & 0.03 & 7.00 & 0.86 & 0.00 & 0.02 \\
\hline & 2014 & 0.11 & 12.54 & 120.00 & 0.11 & 20.00 & 0.55 & 0.20 & 0.03 \\
\hline \multirow[t]{10}{*}{ FCMB } & 2005 & 0.02 & 10.71 & 24.00 & 0.00 & 10.00 & 0.70 & 0.10 & 0.12 \\
\hline & 2006 & 0.01 & 11.03 & 23.00 & 0.06 & 11.00 & 0.73 & 0.00 & 0.07 \\
\hline & 2007 & 0.02 & 11.42 & 24.00 & 0.04 & 12.00 & 0.67 & 0.00 & 0.02 \\
\hline & 2008 & 0.01 & 11.67 & 25.00 & 0.02 & 12.00 & 0.67 & 0.00 & 0.03 \\
\hline & 2009 & 0.02 & 11.66 & 26.00 & 0.07 & 13.00 & 0.62 & 0.00 & 0.03 \\
\hline & 2010 & 0.02 & 11.72 & 27.00 & 0.05 & 13.00 & 0.62 & 0.00 & 0.03 \\
\hline & 2011 & 0.01 & 11.77 & 28.00 & 0.03 & 15.00 & 0.60 & 0.00 & 0.01 \\
\hline & 2012 & 0.02 & 11.96 & 29.00 & 0.03 & 11.00 & 0.91 & 0.00 & 0.01 \\
\hline & 2013 & 0.02 & 12.00 & 30.00 & 0.06 & 11.00 & 0.91 & 0.00 & 0.01 \\
\hline & 2014 & 0.01 & 12.07 & 31.00 & 0.09 & 10.00 & 0.90 & 0.00 & 0.08 \\
\hline \multirow[t]{10}{*}{ GTB } & 2005 & 0.02 & 11.27 & 15.00 & 0.04 & 14.00 & 0.57 & 0.14 & 0.12 \\
\hline & 2006 & 0.01 & 11.48 & 16.00 & 0.03 & 14.00 & 0.64 & 0.14 & 0.10 \\
\hline & 2007 & 0.02 & 11.68 & 17.00 & 0.12 & 11.00 & 0.45 & 0.09 & 0.04 \\
\hline & 2008 & 0.01 & 11.86 & 18.00 & 0.08 & 11.00 & 0.45 & 0.09 & 0.05 \\
\hline & 2009 & 0.07 & 12.03 & 19.00 & 0.09 & 14.00 & 0.57 & 0.21 & 0.05 \\
\hline & 2010 & 0.01 & 12.07 & 20.00 & 0.05 & 14.00 & 0.57 & 0.21 & 0.05 \\
\hline & 2011 & 0.02 & 12.18 & 21.00 & 0.15 & 14.00 & 0.57 & 0.21 & 0.07 \\
\hline & 2012 & 0.22 & 12.21 & 22.00 & 0.10 & 14.00 & 0.57 & 0.21 & 0.07 \\
\hline & 2013 & 0.28 & 12.28 & 23.00 & 0.12 & 14.00 & 0.57 & 0.21 & 0.10 \\
\hline & 2014 & 0.07 & 12.33 & 24.00 & 0.12 & 14.00 & 0.57 & 0.29 & 0.00 \\
\hline \multirow[t]{4}{*}{ SKYE } & 2005 & 0.01 & 10.51 & 43.00 & 0.14 & 17.00 & 0.65 & 0.12 & 0.07 \\
\hline & 2006 & 0.09 & 11.24 & 44.00 & 0.13 & 17.00 & 0.53 & 0.12 & 0.30 \\
\hline & 2007 & 0.01 & 11.65 & 45.00 & 0.06 & 14.00 & 0.57 & 0.07 & 0.06 \\
\hline & 2008 & 0.01 & 11.89 & 46.00 & 0.05 & 17.00 & 0.53 & 0.18 & 0.07 \\
\hline
\end{tabular}




\begin{tabular}{|c|c|c|c|c|c|c|c|c|c|}
\hline & 2009 & 0.05 & 11.79 & 47.00 & 0.00 & 17.00 & 0.53 & 0.18 & 0.05 \\
\hline & 2010 & 0.02 & 11.83 & 48.00 & 0.03 & 17.00 & 0.53 & 0.18 & 0.05 \\
\hline & 2011 & 0.02 & 11.94 & 49.00 & 0.10 & 17.00 & 0.53 & 0.18 & 0.05 \\
\hline & 2012 & 0.04 & 12.03 & 50.00 & 0.11 & 17.00 & 0.53 & 0.18 & 0.05 \\
\hline & 2013 & 0.08 & 12.05 & 51.00 & 0.12 & 17.00 & 0.53 & 0.18 & 0.01 \\
\hline & 2014 & 0.01 & 12.08 & 52.00 & 0.10 & 15.00 & 0.73 & 0.20 & 0.34 \\
\hline \multirow[t]{10}{*}{ STANBIC } & 2005 & 0.02 & 10.59 & 16.00 & 0.33 & 5.00 & 0.60 & 0.40 & 0.29 \\
\hline & 2006 & 0.97 & 11.04 & 17.00 & 0.03 & 8.00 & 0.50 & 1.50 & 0.18 \\
\hline & 2007 & 0.01 & 11.48 & 18.00 & 0.09 & 17.00 & 0.71 & 0.18 & 0.26 \\
\hline & 2008 & 0.01 & 11.54 & 19.00 & 0.04 & 17.00 & 0.71 & 0.18 & 0.26 \\
\hline & 2009 & 0.01 & 11.52 & 20.00 & 0.09 & 13.00 & 0.62 & 0.23 & 0.30 \\
\hline & 2010 & 0.01 & 11.57 & 21.00 & 0.08 & 13.00 & 0.62 & 0.23 & 0.30 \\
\hline & 2011 & 0.01 & 11.74 & 22.00 & 0.09 & 12.00 & 0.92 & 0.25 & 0.30 \\
\hline & 2012 & 0.01 & 11.83 & 23.00 & 0.10 & 12.00 & 0.92 & 0.25 & 0.01 \\
\hline & 2013 & 0.01 & 11.88 & 24.00 & 0.06 & 12.00 & 0.92 & 0.25 & 0.01 \\
\hline & 2014 & 0.01 & 11.98 & 25.00 & 0.07 & 7.00 & 0.86 & 0.43 & 0.13 \\
\hline \multirow[t]{10}{*}{ UBA } & 2005 & 0.02 & 11.40 & 44.00 & 0.01 & 17.00 & 0.53 & 0.18 & 0.00 \\
\hline & 2006 & 0.04 & 11.93 & 45.00 & 0.04 & 14.00 & 0.36 & 0.21 & 0.08 \\
\hline & 2007 & 0.01 & 12.04 & 46.00 & 0.03 & 20.00 & 0.55 & 0.25 & 0.07 \\
\hline & 2008 & 0.01 & 12.18 & 47.00 & 0.05 & 20.00 & 0.55 & 0.25 & 0.02 \\
\hline & 2009 & 0.01 & 12.15 & 48.00 & 0.01 & 19.00 & 0.53 & 0.21 & 0.08 \\
\hline & 2010 & 0.02 & 12.16 & 49.00 & 0.06 & 19.00 & 0.53 & 0.21 & 0.06 \\
\hline & 2011 & 0.03 & 12.22 & 50.00 & 0.08 & 18.00 & 0.56 & 0.22 & 0.08 \\
\hline & 2012 & 0.01 & 12.29 & 51.00 & 0.06 & 18.00 & 0.56 & 0.22 & 0.01 \\
\hline & 2013 & 0.02 & 12.35 & 52.00 & 0.02 & 19.00 & 0.53 & 0.26 & 0.01 \\
\hline & 2014 & 0.02 & 12.37 & 53.00 & 0.05 & 15.00 & 0.60 & 0.27 & 0.09 \\
\hline \multirow[t]{10}{*}{ UNION } & 2005 & 0.02 & 11.74 & 88.00 & 0.28 & 15.00 & 0.53 & 0.07 & 0.00 \\
\hline & 2006 & 0.01 & 11.71 & 89.00 & 0.26 & 17.00 & 0.53 & 0.06 & 0.01 \\
\hline & 2007 & 0.01 & 11.79 & 90.00 & 0.13 & 20.00 & 0.55 & 0.00 & 0.01 \\
\hline & 2008 & 0.01 & 11.96 & 91.00 & 0.08 & 20.00 & 0.55 & 0.10 & 0.01 \\
\hline & 2009 & 0.01 & 12.04 & 92.00 & 0.17 & 20.00 & 0.55 & 0.10 & 0.00 \\
\hline & 2010 & 0.11 & 11.93 & 93.00 & 0.18 & 14.00 & 0.64 & 0.14 & 0.00 \\
\hline & 2011 & 0.24 & 11.92 & 94.00 & 0.03 & 14.00 & 0.79 & 0.14 & 0.00 \\
\hline & 2012 & 0.05 & 11.95 & 95.00 & 0.04 & 14.00 & 0.79 & 0.14 & 0.00 \\
\hline & 2013 & 0.01 & 11.95 & 96.00 & 0.05 & 17.00 & 0.65 & 0.12 & 0.00 \\
\hline & 2014 & 0.01 & 11.96 & 97.00 & 0.08 & 19.00 & 0.68 & 0.11 & 0.00 \\
\hline \multirow[t]{9}{*}{ WEMA } & 2005 & 0.01 & 10.99 & 60.00 & 0.12 & 9.00 & 0.56 & 0.00 & 0.04 \\
\hline & 2006 & 0.01 & 11.08 & 61.00 & 0.11 & 11.00 & 0.64 & 0.00 & 0.08 \\
\hline & 2007 & 0.01 & 11.22 & 62.00 & 0.08 & 7.00 & 0.57 & 0.00 & 0.00 \\
\hline & 2008 & 0.04 & 11.05 & 63.00 & 0.38 & 7.00 & 0.57 & 0.00 & 0.01 \\
\hline & 2009 & 0.38 & 11.15 & 64.00 & 0.61 & 7.00 & 0.57 & 0.00 & 0.01 \\
\hline & 2010 & 0.14 & 11.31 & 65.00 & 0.25 & 7.00 & 0.57 & 0.00 & 0.01 \\
\hline & 2011 & 0.02 & 11.34 & 66.00 & 0.26 & 10.00 & 0.70 & 0.10 & 0.00 \\
\hline & 2012 & 0.02 & 11.39 & 67.00 & 0.23 & 11.00 & 0.64 & 0.09 & 0.00 \\
\hline & 2013 & 0.01 & 11.52 & 68.00 & 0.17 & 11.00 & 0.64 & 0.18 & 0.00 \\
\hline
\end{tabular}




\begin{tabular}{ccccccccccc}
\hline & 2014 & 0.02 & 11.58 & 69.00 & 0.15 & 13.00 & 0.54 & 0.15 & 0.00 \\
\hline ZENITH & 2005 & 0.02 & 11.52 & 15.00 & 0.17 & 12.00 & 0.50 & 0.00 & 0.12 \\
\hline & 2006 & 0.02 & 11.85 & 16.00 & 0.02 & 12.00 & 0.50 & 0.00 & 0.20 \\
& 2007 & 0.01 & 11.95 & 17.00 & 0.02 & 14.00 & 0.50 & 0.00 & 0.08 & 0.13 \\
& 2008 & 0.01 & 12.23 & 18.00 & 0.02 & 14.00 & 0.50 & 0.00 & 0.13 & 0.11 \\
& 2009 & 0.02 & 12.20 & 19.00 & 0.02 & 13.00 & 0.54 & 0.08 & 0.08 & 0.00 \\
& 2010 & 0.02 & 12.25 & 20.00 & 0.02 & 13.00 & 0.54 & 0.15 & 0.00 \\
& 2011 & 0.01 & 12.34 & 21.00 & 0.01 & 13.00 & 0.54 & 0.15 & 0.00 & 0.00 \\
& 2012 & 0.04 & 12.39 & 22.00 & 0.01 & 13.00 & 0.54 & 0.18 & 0.17 & 0.10 \\
\hline
\end{tabular}

Source: Financial Statement-2015.

\section{Copyrights}

Copyright for this article is retained by the author(s), with first publication rights granted to the journal.

This is an open-access article distributed under the terms and conditions of the Creative Commons Attribution license (http://creativecommons.org/licenses/by/3.0/). 